\title{
Revisiting the Relationship between Organisational Commitment and Professional Commitment: A Case Study of Academicians in a Private Educational Institution
}

\author{
NIK MUTASIM AB. RAHMAN \\ MOHMAD ADNAN ALIAS \\ SUHARNI MAULAN \\ Faculty of Economics and Business \\ Universiti Kebangsaan Malaysia
}

ABSTRACT

Many studies have dwelled on various issues related to the concept of commitment. One particular issue concerns the relationship between organisational commitment and professional commitment. Between these foci of commitments, the issue has been whether both are compatible or in conflict - with each other. The nature of the relationship between these variables is worth noting as it may have impact on the behaviour of individuals in organisations, and hence, the formulation and practice of human resource policies in these organisations. This paper reports the findings of a study conducted to investigate this issue of compatibility or conflict between the variables. The unit of analysis were academicians employed in a private research institution in Malaysia. The result of the mail survey revealed the existence of a commitment dilemma within the sample. No significant correlations were - recorded between professional commitment and the various dimensions of organisational commitment. Additionally, professional commitment and organisational commitment correlated significantly with intent to stay in the profession and intent to stay with the organisation, respectively. Directions for further research were also discussed.

Keywords: Organisational commitment; Professional commitment; Intent to stay with the organization; Intent to stay in the profession.

\footnotetext{
ABSTRAK

Banyak kajian telah menyentuh tentang pelbagai isu berhubung dengan konsep komitmen. Satu isu yang menarik perhatian ialah hubungan antara komitmen terhadap organisasi dengan komitmen terhadap profesion. Antara kedua-dua tumpuan komitmen ini, isunya ialah sama ada wujud konflik atau sebaliknya antara satu sama lain. Tabiat hubungan antara kedua-dua tumpuan komitmen ini adalah penting disebabkan kemungkinan wujudnya impak daripada hubungan tersebut ke atas gelagat individu dalam organisasi, yang tentunya akan turut mempengaruhi penggubalan dasar dan amalan sumber manusia. Artikel ini melaporkan dapatan daripada satu kajian yang dijalankan untuk menyelidiki isu konflik atau sebaliknya antara variabel berkenaan. Hasil kaji selidik menunjukkan wujud 'dilema komitmen' dalam sampel yang dikaji. Tidak ada korelasi signifikan dicatatkan antara komitmen terhadap organisasi dengan komitmen terhadap profesion. Selain itu, kajian mendapati komitmen terhadap profesion dan
} 
komitmen terhadap organisasi berkait secara signifikan, masing-masing dengan hasrat untuk kekal dengan profesyen dan organisasi. Cadangan untuk kajian lanjut juga dibincangkan.

\section{Kata kunci: Komitmen terhadap organisasi; Komitmen terhadap profesyen; Hasrat untuk kekal dengan profesyen; Hasrat untuk kekal dengan organisasi.}

\section{INTRODUCTION}

Commitment has notably gained substantial interest among organisational behaviour researchers. Its significance stems from the belief that committed employees will demonstrate differential degrees of organisational outcomes like turnover and performance (Omar \& Aziz, 2002; Meyer \& Allen, 1997). Thus far, studies on commitment have delved into various issues related to the concept, be it conceptual or empirical.

One particular issue that has attracted researchers in the field concerns the various foci of the concept. Employee attachment and commitment are presumed to be associated, not only with the organisation, but also with other "referents" such as profession, family, immediate superior, and religion. Two foci of commitment that have received relatively more attention than the others, which are organisation and profession

(Mathieu \& Zajac, 1990). Between these objects of commitment, the issue has been whether both are compatible or in conflict with each other. The nature of the relationship between these foci of commitment is worth noting as it may have impact on the behaviour of individuals in organisations, and hence, may have implications - on the formulation and practice of human resource policies in these organisations.

In Malaysia, studies that investigate the relationship between these foci of commitment ate, obviously, lacking. An attempt to address the research gap was conducted by Nik Mutasim and Mohd Hizam (2002). Using a sample of research scientists, these authors found out that commitment to a profession was positively related to all the dimensions of organisational commitment studied.

In light of the need to establish more empirical evidence in the Malaysian context, this research aimed to seek answers to whether within a different sample, compatibility or conflict prevails in the relationship between these commitment variables. Specifically, this study attempts to explore whether significant relationships exist between levels of professional commitment and levels of employees' organisational affective, continuance, and normative commitment.

\section{The Concept of Organisational Commitment}

Conceptually, organisational commitment has been defined in various ways. A plethora of definitions can be found in commitment literatures. Table 1 (in the appendix) demonstrates some of these definitions.

A close examination of these definitions reveals the inconsistency underlying the understanding of the concept of commitment among researchers. In their review of the conceptualisation of commitment, Mathieu and Zajac (1990) suggested that these definitions signify a unidimensional nature of the concept. Allen and Meyer (1990) went further to propose that commitment, instead, should be conceived as multidimensional. Accordingly, in their proposed three component commitment model, these authors suggested that commitment can be categorised into three different dimensions, namely affective, continuance, and normative dimensions.

Affective commitment refers to the employees' emotional attachment to, identification with, and involvement in the organisation. Employees with a strong degree of affective commitment continue employment with the organisation because they want to do so. Continuance commitment refers to an awareness of the costs associated with leaving the organisation. Employees whose primary link to the organisation is based on continuance commitment remain because they need to do so. Finally, normative commitment reflects a feeling of obligation to continue employment. Employees with a high 
degree or level of normative commitment feel that they ought to remain with the organisation.

\section{The Concept of Commitment to Profession}

Professional commitment has also been identified as career commitment (Mueller, Wallace, \& Price, 1992); career salience (Randall \& Cote, 1991); occupational commitment (Ritzer \& Trice, 1969); and "cosmopolitan-local" distinction (Gouldner, 1957). According to Sorensen and Sorensen (1974), this construct can be defined in a number of ways, which includes an individual's identification with and involvement in the profession; commitment and dedication to the - profession; and acceptance of professional ethics and goals. The term "profession", which has yet to have a single, authoritative, and universally accepted definition, as shown, is the object of professional commitment in all these definitions. Despite the ambiguities in its definition, - profession, according to Alexander (1981) and Kozlowski and Hults (1986), can generally be identified by the following characteristics: a common body of knowledge; autonomy in the application of that knowledge; commitment to a specialised line of work; identification with the line of work; responsibility to society for the ethical use of specialised knowledge; and collegial maintenance of performance standards.

\section{The Relationship Between Organisational} Commitment and Commitment to

\section{Profession}

As mentioned earlier, the underlying the relationship between commitment to the organisation and commitment to profession is the issue of conflict or compatibility. This issue, according to Mueller et al. (1992) emerges as the nature of the workforce changes toward increasing levels of education and professionalism. These changing trends have also led to the identification of two categories of professional employment: 1) professionals working in professional organisations and 2) professionals employed in non-professional organisations. Scott (1965) had earlier identified professional organisation or settings as those where the majority of members are professionals; the professional content of work is central to the mission of the organisation; and the goals of the organisation are largely consistent with those of the professionals employed. Wallace (1995) cited medical clinics, research institutes, architectural offices, accounting firms, and law firms as examples of such organisations. Variations in employment settings, thus, have often been speculated to be a determinant of the nature of the relationship between the professionals' identification with their organisations and their identification with the values and norms of their professions. Non-professional organisations, in particular, are assumed to be more bureaucratic than the professional organisations (Wallace, 1995). On the other hand, it is possible that some individuals, irrespective of whether they are working in professional or non-professional organisations, may respond more as professionals than do others. These complexities may result in inconsistent value systems, which, as emphasized by Lachman and Aranya (1986), may lead to a commitment dilemma. This subsequently may influence other work attitudes and behaviours, such as job satisfaction, behavioural intentions, and turnover (Mueller et al., 1992; Bartol, 1979).

The literature thus far, has exposed two different views with regard to the professional commitment-organisational commitment relationship. Kornhauser (1962), Blau and Scot (1962), Scott (1966), Alexander (1981), Hall (1968), and Howell and Dorfman (1986) are examples of authors who had identified the presence of conflict between organisational and professional commitment. Professional employees, as they argued, tend to be more committed to their profession and its values than to their employers or organisations. Kallerberg and Berg (1987) described the conflict between commitment to profession and commitment to organisation as resembling the zero-sum game concept, whereby an increase in the level of commitment to profession, for instance, will result in a decline in commitment to organisation, and vice versa. A few other authors, Sorensen and Sorensen (1974), Miller (1967), La Porte (1965), and Howell and Dorfman (1981), for example, have suggested 
that bureaucratic organisational structures result in restrictions on professional autonomy. The professional and organisational-bureaucratic value systems have often been regarded as incompatible or in conflict with each other, and associated with different role orientations. While the organisational-bureaucratic value system is assumed to be characterised by values such as hierarchical control and authority, conformity to organisational goals, norms and regulations, and organisational loyalty, the professional value system is known to emphasise values such as collegiality, professional control, conformity to professional standards and goals, professional autonomy, and client orientations and loyalty (Corwin, 1961; Lachman \& Aranya, 1986).

The notion of conflict between these two forms of commitment, however, has not been well accepted by some other researchers. Aranya, Kushnir, and Valency (1986), Hrebiniak and Alutto (1972), Organ and Greene (1981), and Podsakoff, Williams, and Todor. (1986), for example, suggested that there is a growing interpenetration of professional and bureaucratic characteristics at work. This has lead to the contra assumption that there is no inherent conflict between commitment to the profession and the organisation, provided the individuals' professional work expectations and goals are met by the employing organisation. In other words, the commitment dilemma, as mentioned above, is assumed to be non-existent. This view has also been supported by Aranya and Jacobson (1975) and Aranya and Ferris (1983). Becker (1992), though still consistent with the preceding view but in a slightly different - tone, proposed that employees may have a high degree of commitment to both their employing rganisation and profession. Both forms of commitment, in other words, are assumed to be compatible or complementary to each other and may occur simultaneously. In this context, Baugh and Roberts (1994) suggested that the simultaneous occurrence of high levels of both forms of commitment may be desirable for the organisation, and could act as a check and balance tool for each other. High professional commitment, for instance, may absorb some of the dysfunction of high commitment to the organisation, such as the organisation man syndrome. Likewise, high professional commitment, alone, without the support of a reasonable level of organisational commitment, can be of less utility, as it may result in high quality work being produced, but work which is not maximally tailored to the organisation's needs. It too, as Greene (1978) suggested, may cause role conflict and alienation. Baugh and Roberts (1994) further suggested that the interaction of professional commitment with organisational commitment should provide a better prediction of job satisfaction than professional commitment or even organisational commitment alone. In addition, the authors also indicated that tenure with the organisation has the potential for the influence attributable to both forms of commitment.

\section{EMPIRICAL EVIDENCE}

Based on the review of empirical research on professional commitment, it was found that thus far, not much attention has been offered by researchers to assessing this professional commitment-organisational commitment relationship, or the commitment dilemma. Wallace (1993), in her literature search for a meta-analytic study of the relationship between professional commitment and organisational commitment for the period from 1966 until 1989, identified only 25 studies that met her selection criteria for analysis. These criteria included studies that reported correlation coefficients between both forms of commitment and those which referred to commitment in the context of work. Many previous studies on this subject, according to Wallace, were in the form of theoretical articles and literature reviews.

A summary of past empirical studies reviewed by the present researcher, which includes studies employed in Wallace's meta-analytic study, is presented in Table 1. Most of the studies used affective commitment measures, i.e., the Organisational Commitment Questionnaire (OCQ) in their investigations. Thus, essentially, the assessment of the professional commitmentorganisational commitment relationship in most of these studies was basically unidimensional and limited to only organisational affective 
commitment. While three studies were identified to have used behavioural commitment measures (Ritzer \& Trice, 1969; Aranya \& Ferris, 1983), only Mathieu and Zajac's (1990) meta-analytic study explicitly differentiated the relationship between professional commitment and the different forms of organisational commitment. Besides revealing a positive relationship between organisational commitment (using the overall scale) and professional commitment, Mathieu and Zajac also reported a stronger Pelationship between professional commitment and organisational affective commitment than professional commitment with organisational - continuance commitment. According to them, studies that examine the relationship between professional commitment and other dimensions of commitment, apart from organisational affective commitment, are still scarce. More research, as the authors suggested, is needed to validate existing findings and explore further the nature of relationship between both types of commitment. Apart from these observations, it can also be seen from Table 1 that statistically, the correlation coefficients representing the professional commitment-organisational commitment relationship range between -.06 to .72. This suggests a considerable degree of inconsistency in the pattern of relationship between the variables, which may imply the nature of the strength of compatibility or conflict between these two forms of commitment.

\section{Table 1}

Summary of Studies Examining the Correlation Coefficient between Professional and Organisational Commitment

\begin{tabular}{|c|c|c|c|}
\hline Study & Sample & $\mathrm{N}$ & Correlation coefficient \\
\hline 1. Ritzer \& Trice (1969) & Personal managers & 419 & $.30^{\mathrm{a}}$ \\
\hline 2. Rotondi (1975) & $\begin{array}{l}\text { Business graduates-non } \\
\text { managers }\end{array}$ & 47 & .20 \\
\hline 3. Rotondi (1975) & $\begin{array}{l}\text { Business graduates } \\
\text {-managers }\end{array}$ & 140 & .43 \\
\hline 4. Wiener \& Vardi (1980) & Insurance agents & 56 & .32 \\
\hline $\begin{array}{l}\text { 5. Aranya, Pollock, \& } \\
\text { Amernic (1981) }\end{array}$ & Staff professionals & 85 & -.06 \\
\hline 6. Aranya et al. (1981) & Accountants & 90 & .36 \\
\hline 7. Aranya et al. (1981) & Accountants & 173 & .52 \\
\hline 8. Aranya et al. (1981) & Accountants & 344 & .41 \\
\hline 9. Ferris (1981) & Accountants & 123 & .23 \\
\hline 10. Ferris (1981) & Accountants & 46 & .25 \\
\hline 11. Aranya \& Ferris (1983) & Accountants & 404 & $.72^{\mathrm{a}}$ \\
\hline 12. Aranya \& Ferris (1983) & Accountants & 469 & $.39^{\mathrm{a}}$ \\
\hline 13. Aranya \& Ferris (1984) & Accountants & 1074 & .45 \\
\hline 14. Aranya \& Ferris (1984) & $\begin{array}{l}\text { Accountants in non } \\
\text {-professional organisations }\end{array}$ & 942 & .14 \\
\hline 15. Blau (1985) & Registered nurses & 119 & .18 \\
\hline 16. Aranya et al. (1986) & Accountants & 1053 & .46 \\
\hline
\end{tabular}


(continued)

\begin{tabular}{|c|c|c|c|}
\hline 17. Lachman \& Aranya (1986) & Accountants & 344 & .47 \\
\hline 18. Lachman \& Aranya (1986) & Accountants & 150 & .51 \\
\hline 19. Lachman \& Aranya (1986) & $\begin{array}{l}\text { Accountants in non- } \\
\text { Professional organisations }\end{array}$ & 298 & .19 \\
\hline 20. Morrow \& McElroy (1986) & Supervisory employees & 563 & .40 \\
\hline 21. Pazy \& Zin (1987) & Wide range of professionals & 175 & .62 \\
\hline 22. Blau (1988) & Supervisors & 137 & .33 \\
\hline 23. Blau (1988) & Insurance personnel & 106 & .31 \\
\hline 24. Stefy \& Jones (1988) & Registered nurses & 118 & .32 \\
\hline 5. Morrow \& Wirth (1989) & $\begin{array}{l}\text { University scientists and } \\
\text { professional staff }\end{array}$ & 728 & .34 \\
\hline Mathieu \& Zajac (1990) & Meta-analytic study & - & $\begin{array}{l}.42 \\
.50 \\
.45^{\mathrm{c}}\end{array}$ \\
\hline 7. Wallace (1993) & Meta-analytic study & - & .45 \\
\hline $\begin{array}{l}\text { 8. Nik Mutasim \& Mohd } \\
\text { Hizam (2002) }\end{array}$ & Research scientists & 545 & $\begin{array}{l}.43^{\mathrm{c}} \\
.15^{\mathrm{b}} \\
.52^{\mathrm{d}}\end{array}$ \\
\hline $\begin{array}{l}\text { 29. Leong, Huang \& } \\
\text { Hsu (2003) }\end{array}$ & Auditors & 1206 & .54 \\
\hline
\end{tabular}

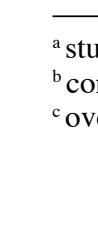

udies using measures of behavioural commitment

continuance commitment

overall commitment d normative commitment

The meta-analytic studies (by Wallace and Mathieu and Zajac) also seem to support no conflict situation between the two forms commitment. Wallace's study, for example, evealed a true correlation of the order of .45 , indicating a moderately strong association. Further scrutiny of these studies, however, suggests that more evidence needs to be produced before such conclusions can be convincingly confirmed.

- Wallace, in her study, cautioned the fact that, While the majority of studies had employed North American samples, more than half were accountants. It is reasonable, thus, according to this author to expect or speculate that variations sample characteristics, i.e. across cultures and types of professions, may possibly produce different results.

Wallace's study, in addition, suggested the importance of considering potential moderating effects on the magnitude and/or direction of the association between professional commitment and organisational commitment. Wallace mentioned the likelihood of two variables - the degree of professionalisation of employees' occupations and employees' designation or position in the authority hierarchy - as the sources of these potential moderating effects. The degree of professionalisation relates to the nature of the profession, i.e. whether the professions are technical-scientific (e.g., engineering, science) or personalised (e.g., law, medicine, teaching). Wallace, in this respect, adopted Hall's (1968) categorisation of the degree of professionalisation into high and low professionalisation. High professionalisation includes staff professionals, accountants, nurses, and scientific university staff. Low professionalisation, on the other hand, consists of professionals belonging to occupations such as personnel managers, business graduates, insurance agents, accountants in non-professional organisations, and supervisory staff. The results of her study suggested that the higher the professionalisation of the occupation, the higher the association between professional commitment and organisational commitment. 
With respect to the employees' rank or position in the organisation, Wallace found that a stronger correlation between professional commitment and organisation persists within the ranks of professionals who hold higher positions (i.e. managers) than ordinary professional staff. This may be explained by the fact that managerial positions reflect a greater degree of responsibility as well as benefits The benefits, particularly, could well represent investments gained by the professional managers. Through higher positions, individuals' professional and organisational roles may be more highly integrated. Both investments and integration of roles, thus, may combine to - contribute to a higher degree of compatibility in the professional-organisational relationship.

Lachman and Aranya (1986), in their study of a sample of Canadian Certified Accountants, apart from revealing some degree of congruence in the values and norms of the profession and organisation, also investigated the possibility of organisational settings moderating employees' professional commitment-organisational commitment relationship. This possibility was not examined by Wallace (1993). Lachman and Aranya found that accountants in professional settings are more committed to the profession than their colleagues in non-professional settings. There is evidence, thus, for organisational setting to constitute another important moderating factor in influencing employees' organisational commitment-professional commitment relationship.

A more recent source of evidence of the professional commitment-organisational commitment relationship can be found in the works of Baugh and Roberts (1994) who studied a sample involving 149 engineers in a U.S. Government military depot. A total of 114 engineers, the majority of them (94\%) male, responded. Professional commitment was assessed by a three item measure adopted from Kerr and Jermier (1978). They also included job satisfaction, measured by the Minnesota Satisfaction Questionnaire (MSQ). Baugh and Roberts hypothesised and tested the existence of significant interaction effects between organisational affective commitment and professional commitment on job satisfaction (controlling for organisational tenure) with individuals high in both commitments reporting the highest job satisfaction (p.110). Using a 2 X 2 analysis of covariance (ANCOVA), with tenure in the organisation as the covariate, the authors found support for their hypothesis. Organisational affective commitment was found to have a significant main effect on job satisfaction, and a significant interaction between organisational affective commitment and professional commitment existed. The highest levels of satisfaction were reported by individuals high on both forms of commitment. Baugh and Roberts concluded that there is a complementary, rather than conflicting or mutually exclusive relationship, between the two constructs. In their comments on this relationship, the authors noted:

\begin{abstract}
Organisational commitment (i.e., organisational affective commitment) may serve as a motivational factor for higher job performance. Professional commitment may represent a capability factor. Engineers high on this factor are more likely to stay current in their profession and therefore will be more capable of job contributions. Or perhaps professional commitment is a second motivational factor, leading engineers to strive for high quality work. These combinations of motivation and ability may result in the higher levels of performance (or other work outcomes)(p.112).
\end{abstract}

\section{RESEARCH METHODOLOGY}

Data was collected through a survey conducted on academicians of a private educational institution having several campuses throughout peninsular Malaysia. Overall, this institution employed a total number of 300 lecturers. Considering the relatively small number of lecturers, questionnaires were sent by mail together with a self-addressed stamped envelope. The total number of returned questionnaires were 148, 
i.e. comprising approximately of $62 \%$ of the total respondents. However, for the purpose of analysis, only 118 were deemed usable. Table 2 demonstrates the respondents' profile.

Table 2

Sample Characteristics

\begin{tabular}{lll}
\hline Demographic characteristics & Number of sample (n) & Percentage (\%) \\
\hline
\end{tabular}

Gender:

$\checkmark$ Male

Female

20

16.9

98

83.1

Status of employment:

Permanent

77

65.3

Temporary/on contract

41

34.7

Age:

25 years

26-30 years

1-35 years

36-40 years

$\rightarrow 40$ years

31

26.3

38

32.3

33

12

28.0

10.2

4

3.4

Race:

Malay

Non-Malay

$\begin{array}{cc}116 & 98.3 \\ 2 & 1.7\end{array}$

Marital Status:

Married

67

56.8

51

43.2

Single

90

76.3

Level of education:

Bachelor's degree

28

23.7

Masters degree

Tenure with the

Organisation:
- $<1$ year
$1.1-5$ years
$1-10$ years
10 years

(3)

Tenure with the profession:

$<1$ year
$1.1-5$ years
$5.1-10$ years
$>10$ years

\section{Experience in other}

Profession:

Yes

No 


\section{(continued)}

Work experience in other organisations:

Yes

The measures of organisational commitment were adopted and modified from measures developed by Meyer, Allen, and Smith (1993). The original instrument consisted of 22 statements. However, in this study, only 19 statements were chosen to represent the construct. While 7 statements measured affective commitment, another 7 measured normative commitment, while the 8 remaining statements measured continuance commitment. Based on previous studies of Nik Mutasim and Mohd Hizam (2002), not all of the original items meant to measure affective commitment and normative commitment were included due to their inability to contribute significantly to better reliability coefficients of the respective measures. On the other hand, all items measuring continuance commitment were fully adopted in view of the fact that these items needed to be included in order to achieve a higher degree of reliability for this dimension of commitment.

Commitment to profession were measured using items developed by Porter et. al (1974).

However, Porter's organisational commitment questionnaire (OCQ), as it is widely known, was slightly changed or modified. The reference with respect to the organisation in the statements was changed to profession. Altogether, five items measured this construct and all items were positively worded.

Apart from the commitment variables, intention to stay with the organisation and intention to stay in the profession were included in the questionnaire. Although these variables do not directly serve to address the research objective, the inclusion of these outcome variables of commitment would, additionally, help to enhance the understanding of the nature of the relationship between the key research variables.

While intention to stay with the organisation was measured using four statements developed by Kim et al. (1996), the measures for intention to stay in the profession were adopted from
Weisberg (1994). The latter also comprised of four statements. For all the key research variables, a Likert scale on points ranging from 1 to 5 was adopted, with 1 representing strongly disagree to 5 , strongly agree.

\section{RESULTS AND DISCUSSION}

\section{Factor Analysis}

In this study, a confirmatory factor analysis was conducted on the organisational commitment measures. Using a principal component for varimax rotation, the analysis generated three factors (KMO measure of sampling adequacy, 0.866; Chi-square value of 986.39 from Bartlett's test of sphericity significant at $\mathrm{p}<0.001$; and total variance of $54.76 \%$ ). The factor loadings for each factor are presented in the Table 3 in the Appendix. As can be seen in the table, most of the items measuring continuance commitment converged in Factor 2. While there is no clear representation of any dimension of commitment that can be observed in Factor 3, a mixture of items measuring affective and normative dimensions of commitment pooled together in Factor 1. This resulting of factor analysis does not appear to fully support Allen and Meyer is (1990) proposition that there are three distinct dimensions of commitment, namely, affective, continuance, and normative commitment. This inconsistency could be due to the limited number of usable responses obtained from the survey. Hence, for further analysis of the data in this study, the outcome of factor analysis was not considered. Instead, the predetermined measures of each study variables were used.

Table 3 shows the reliability coefficients obtained for each of the variables. As can be seen from the table, Cronbach alpha values ranged from 0.76 to 0.87 . Compared to alpha values 
generated in previous studies (e.g., Nik Mutasim \& Mohd Hizam, 2002), the outcome from this study could be described as acceptable and satisfactory. Statistically, the results also imply that the measures could be appropriately utilised for further analyses.

Table 3

Alpha Coefficients of Key Research Variables

\begin{tabular}{lc}
\hline Research Variables & Alpha Coefficient \\
\hline Affective commitment & 0.8709 \\
Continuance commitment & 0.7760 \\
Normative commitment & 0.7867 \\
Commitment to profession & 0.8758 \\
Intent to stay in organisation & 0.7994 \\
Intent to stay in profession & 0.7641 \\
\hline
\end{tabular}

\section{Table 4}

Means and Standard Deviations of the Key Research Variables

Key Research Variables

Affective commitment

Continuance commitment

Normative commitment

Commitment to profession

Intent to stay in organisation

Intent to stay in profession
Mean

2.8856

2.9976

2.6424

4.2932

2.5657

4.0826
Standard Deviation

0.7691

0.7525

0.7525

0.5804

0.8576

0.7251

$=118$

\section{Descriptive Analysis}

- Table 4 demonstrates the means and standard deviations of the key research variables for he whole sample $(n=118)$. With respect to organisational commitment, continuance commitment registered the highest mean value (2.99), followed by affective commitment (2.88), and normative commitment (2.64). In the context of the study sample, this appears to be somewhat surprising considering in past studies, e.g. Nik Mutasim (2001) and Zain (1996), affective commitment recorded the highest mean value compared to the other dimensions of commitment. The fact that respondents, on average, scored highest in their levels of continuance commitment, could well suggest that their attachment with the organisation has been basically to satisfy their material needs. This could be further implied by the relatively low mean value recorded for their intent to stay in the organisation (2.56). In Meyer and Allen's (1991) interpretation, the results might suggest that the majority of the respondents stay in the organisation, primarily, not because they need to do so or because they ought to do so, but rather because they have to do so. In other words, the prime consideration of their attachment with the organisation has to do with their perceived costs of leaving the organisation. 
For professional commitment, respondents indicated a high degree of attachment to their teaching profession (4.29). This, somewhat represents a notable contrast with the respondents' commitment to the organisation. A big contrast could also be observed in the mean values obtained for the respondents' intent to stay in their profession (4.08) and their intent to stay with the organisation (2.56).

\section{Correlation Analysis}

Table 5 presents the results of the correlation analysis involving all the key research variables. As can be observed from the table, all three dimensions of organisational commitment are significantly correlated with each other. A moderately high degree of correlations registered between affective commitment and normative commitment is expected considering these dimensions are both attitudinal in nature. - A lower degree of relationship recorded between both these attitudinal dimensions of commitment and continuance commitment is also expected. However, the fact that the correlations are significant, is least expected considering that the majority of past studies registered insignificant relationship between the variables. The latter outcome was often cited as evidence to suggest that both affective and normative dimensions of commitment, and continuance commitment are independent constructs. Hence, in this study, the results suggest the opposite.

From Table 5, it could also be observed that there are no significant relationships between all three dimensions of organisational commitment and the respondents' commitment to the teaching profession. While a significant relationship was established between commitment to profession and the respondents' intent to stay in the teaching profession, no significant relationships could be observed with respect to the link between all dimensions of organisational commitment and the intent to stay in the profession. Likewise, no significant relationship was also noted between the commitment to profession and intent to stay in the organisation. These results were consistent with the evidence from the descriptive statistics presented earlier in Table 4 which found an obvious contrast in the means achieved between the dimensions of organisational commitment and commitment to profession. Based on these findings, it could very well imply that there exist potential conflict between organisational commitment and professional commitment. In other words,

Table 5

Zero Order Pearson Correlation Coefficients of Key Research Variables

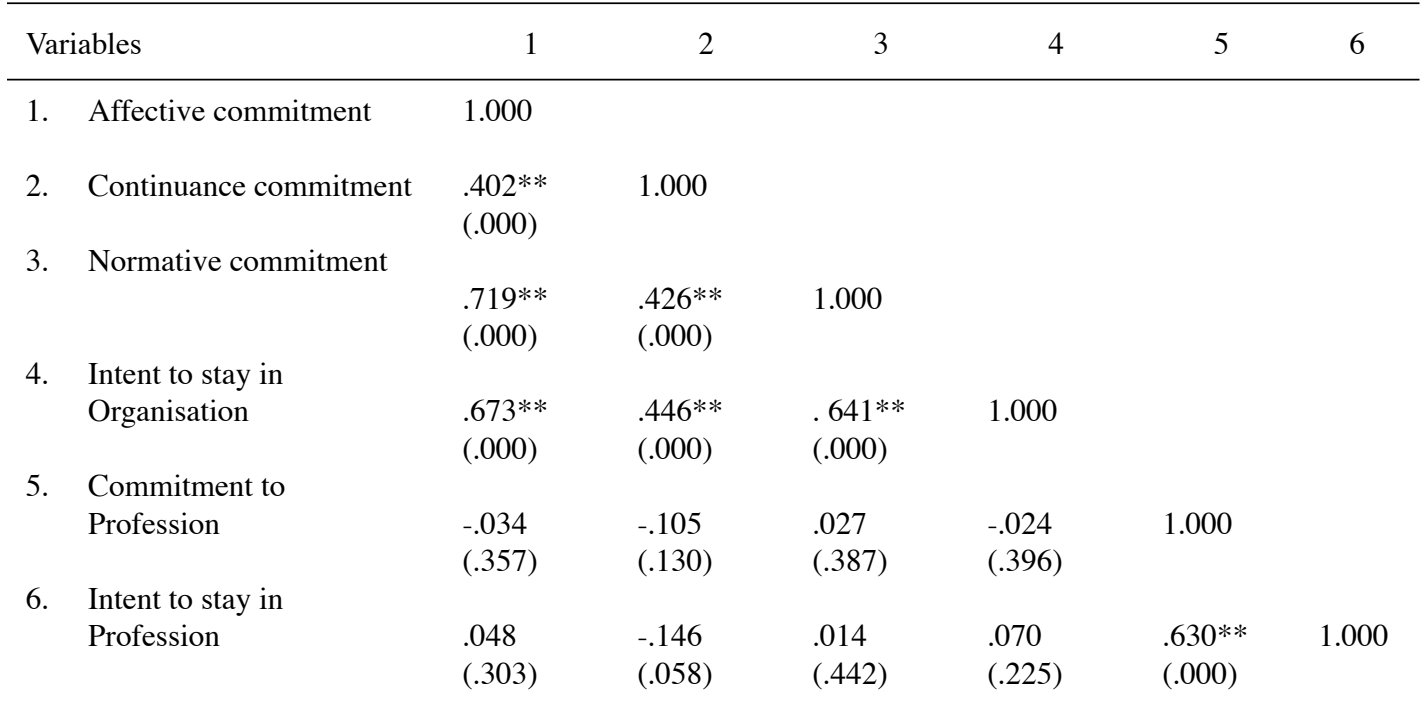


a commitment dilemma could possibly exist, at least with respect to the sample employed in this study. Hence, it follows that, an individual might be less committed to the organisation, but more committed to the profession. It would not be surprising if a person of this nature could continue to stay in the organisation.

\section{CONCLUSION}

This study has revealed that individuals might experience a commitment dilemma in his or her working life. One could be highly committed in his or her profession as an academician, but might not be committed to the organisation. Perhaps, the opposite of this phenomenon could also occur, i.e. an individual might be highly Committed to his organisation be less committed to his or her profession.

Apart from this finding, the study also confirmed that individuals with high levels of professional commitment would also experience a high level of intent to stay in the profession. Dikewise, employees recording a high degree of commitment to the organisation would - tend to have a high degree of intent to stay in the organisation. However, no significant relationship was registered between the employees' professional commitment and their intent to stay in the organisation. Similarly, employees' scoring highly on organisational commitment might have nothing to do with their intent to stick with their - profession.

Theoretically, the findings of this study have complemented the existing evidence in the field, in particular, with respect to the topic thder study. Certainly, the fact that organisational commitment was found to be in conflict with professional commitment implies the need for more revisits in terms of further empirical research. Investigations using other types of samples and a larger sample size, would obviously be interesting. Only then, perhaps the issues of consistency and generalisation in the findings could be better evaluated.

\section{REFERENCES}

Alexander, K.O. (1981). Scientists, Engineers and the Organisation of Work. American Journal of Economics and Sociology, 40,1, 51-66.

Allen, D. B., \& Meyer J. P. (1990). The measurement and antecedents of affective, continuance, and normative commitment to the organisation. Journal of Occupational Psychology, 63, 1-18.

Alutto, J. A., Hrebiniak, L. G., \& Alonso, R. (1973). On operationalizing the concept of commitment. Social Forces, 51, 448-454.

Angle, H. L., \& Perry, J. L. (1983). Organisational commitment: Individual and organisational influences. Work and Occupations, 10, (2), 123-146.

Aranya, N., \& Ferris, K. R. (1983). Organisationalprofessional conflict among US and Israeli professional accountants. Journal of Social Psychology, 119, 153-161.

Aranya, N., \& Jacobson, D. (1975). An empirical study of theories of organisational and occupational commitment. Journal of Social Psychology, 97, 15-22.

Aranya, N., Pollock, J., \& Amernic, J. (1981). An examination of professional commitment in public accounting. Accounting, Organisations and Society, 6, 271-280.

Aranya, N., Kushnir, T., \& Valency.A. (1986). Organisational commitment in a maledominated profession. Human Relations, 39, (5), 433-448.

Bartol, K. M. (1979). Individual versus organisational predictors of job satisfaction and turnover among professionals. Journal of Vocational Behaviour, 15, 55-67. 
Baugh, S. G., \& Roberts, R. M. (1994). Professional and organisational commitment among engineers: Conflicting or complementing? IEEE Transactions on Engineering Management, 41, 2, May, 108-114.

Becker, T. E (1992) Foci and bases of commitment: Are They Distinctions Worth Making? Academy of Management Journal, 35, N0.1,232-244.

Becker, T. E., \& Billings, R. S. (1993). Profiles of commitment: An empirical test. Journal of organisational behaviour, 14, (2), 177190.

Blau, P. M., \& Scot, W. R. (1962). Formal organisations. San Francisco, Chandler.

Buchanan, B. (1974). Building organisational commitment: The socialization of managers in work organisations. Administrative Science Quarterly, 19, 533- 546.

Corwin, R. G. (1961). The professional employee: A study of conflict in nursing roles. American Journal of Sociology, 66, 604615.

Ferris, K. R., \& Aranya, N. (1983). A Comparison of Two Organisational Scales. Personnel Psychology, 36, 87-97.

Gouldner, A. W. (1957). Cosmopolitans and locals: Towards an analysis of latent social roles. Administrative Science Quarterly, 2, 281-306.

Greene, C. N. (1978). Identification modes of professionals: Relationship with formalization, role strain and alienation. Academy of ManagementJournal, 21, 426492.

Hall, D. T., \& Schneider, B. (1972). Correlates of Organisational Identification as a Function of Career Pattern and Organisational Type. Administrative Science Quarterly, 17, 340-350.
Hall, D. T., Schneider, B., \& Nygren, H. T. (1970). Personal Factors in Organisational Identification. Administrative Science Quarterly, 15, 176-190.

Hall, R. H. (1968). Professionalisation and bureaucratization. American Sociological Review, 33, 195-212.

Hoff, T. J., \& Mandell, J. (2001). Exploring dual commitment among physician executives in managed care/practioner application. Journal of Healthcare Management, 46 (2). 91-111.

Howell, J. P., \& Dorfman, P. W. (1986). Leadership and Substitutes for Leadership among Professional and Non-Professional Workers. Journal of Applied Behavioural Science, 22 (1), 29-46.

Hrebiniak, L. G., \& Alutto, J. A. (1972). Personal and role-related factors in the development of organisational commitment. Administrative Science Quarterly, 17, 555-573.

Hrebiniak, L. G. (1974). Effects of job level and participation on employee attitudes and perception of influence. Academy of Management Journal, 17, 649-662.

Jaros, S. J., Jermier, J. M., Koehler, J. W., \& Sincich, T. 1. (1993). Effects of continuance, affective, and moral commitment on the withdrawal process: An evaluation of eight structural equation models. Academy of Management Journal, 36, 951-995.

Kallerberg, A., \& Berg, I. (1987). Work and industry: Structures, markets and processes New York: Plenum.

Kanter, R. M. (1968). Commitment and social organisation: A Study of commitment in Utopian communities. American Sociological Review, 33, 499-517. 
Kanter, R. M. (1977). Work and family in the United States: A critical review and agenda for research and policy. Russel Sage, New York.

Keller, R. T. (1984). The role of performance and absenteeism in the prediction of turnover. Academy of Management Journal, 27, 176-183.

Kerr, S., \& Jermier, J. M. (1978). Substitutes for leadership: Their meaning and measurement. Organisational Behaviour and Human Performance, 22 (3), 375403.

Kornhauser, W. (1962). Scientists in industry, University of California Press, Berkeley, CA.

Kozlowski, S. W. J., \& Hults, B. M. (1986). Joint moderation of the relation between task complexity and job performance for engineers. Journal of Applied Psychology, 71 (2), 196-202.

Lachman, R., \& Aranya, N. (1986). Evaluation of alternative models of commitments and job attitudes of professionals, Journal of Occupational Behaviour, 7, 227-243.

arson, E. W., \& Fukami, C. V. (1984). Relationship between worker behaviour and commitment to the organisation and union. Proceedings of the Academy of Management, 222-226.

ng, L., Huang, S. Y., \& Hsu, J. (2003). An empirical study on professional commitment, organisational commitment and job involvement in Canadian accounting firms. Journal of American Academy of Business, 2, (2), 360-371.

Marsh, R. M., \& Mannari,H. (1977). Organisational commitment and turnover: A predictor study. Administrative Science Quarterly, 22, 57-75.
Mathieu, J. E., \& Zajac, D. M. (1990). A Review and Meta-Analysis of the Antecedents, Correlates, and Consequences of Organisational Commitment. Psychological Bulletin, 108, (2), 171-194.

Meyer, J. P., \& Allen, N. J. (1991). A threecomponent conceptualisation of organisational commitment. Human Resource Management Review. 1, (1), 61-89.

Meyer, J. P., \& Allen, N. J. (1987). A Longitudinal Analysis of the Early Development and Consequences of Organisational Commitment. Canadian Journal of Behavioural Science, 19, 199-215.

Meyer, J. P., \& Allen, N. J. (1997). Commitment in the workplace: Theory, research and application. California: Sage publications.

Meyer, J. P., Allen, N. J., \& Gellatly. (1990). Affective and Continuance Commitment to the Organisation: Evaluation of measures and analysis of Concurrent and TimeLagged Relations. Journal of Applied Psychology, 75, (6), 710-720.

Meyer, J. P. Allen, N. J. \& Smith, C. A., (1993). Commitment to organisations and occupations: extension and test of a threecomponent conceptualisation. Journal of Applied Psychology, 78, (4), 538-551.

Meyer, J. P., Paunonen, S., Gellatly, I., Goffin, R., \& Jackson, D., (1989). Organisational commitment and job performance: It's the nature of the commitment that counts. Journal of Applied Psychology. 74, (1), 152-156.

Mobley, Griffeth, Hand \& Meglino Model. Journal of Applied Psychology, 67, 53-59.

Miller, G. A. (1967). Professionals in bureaucracy: Alienation among industrial scientists and engineers. American Sociological Review, 32, 755-768. 
Morrow, P.C., \& Wirth, R. E. (1989). Work commitment among salaried professionals. Journal of Vocational Behaviour, 34, 4056.

Mowday, R., Porter, L., \& Steers, R. (1982). Employee-organisation linkages: The psychology of commitment, absenteeism, and turnover. New York. Academic Press.

Mueller, C. W., Wallace, J. E., \& Price, J. L. (1992). Employee commitment: Resolving some issues. Work and Occupations, 19, (3), 211-236.

Nik Mutasim (2001). A multidimensional approach to the study of organisational commitment: Empirical evidence from a Malaysian context. $\mathrm{PhD}$ Thesis. University of Strathclyde.

Nik Mutasim Ab. Rahman., \& Mohd Hizam Hanafiah (2002). Commitment to organisation versus commitment to profession: Conflict or compatibility, Jurnal Pengurusan, 21, 79-96.

Omar Samad Abd., \& Aziz Ibrahim (2002). Membentuk nilai positif dan komitmen pekerja dalam organisasi. Dewan Ekonomi, February, pp. 32-33.

Organ, D. W., \& Greene, C. N. (1981). The effects of formalization on professional involvement. Administrative Science Quarterly, 26, 237-252.

Podsakoff, P. M., Williams, L. J., \& Todor, W. D. (1986). Effects of organisational formalization on alienation among professionals and non-professionals. Academy of Management Journal, 29, 820-831.

Randall, D. (1987). Commitment and the organisation: The organisation man revisited. Academy of Management Review, 12, (3), 460-471.
Randall, D. (1990). The consequences of organisational commitment: A methodological investigation. Journal of Organisational Behaviour, 11, 361-378.

Randall, D. M. (1993). Cross-cultural research on organisational commitment: A review and application of of hofstede's value survey module. Journal of Business Research, 26, 91-110.

Randall, D. M., \& Cote, J. A. (1991). Interrelationships of work commitment constructs. Work and Occupations, 18, 194-211.

Ritzer, G., \& Trice, H.M. (1969). An Empirical Study of Howard Becker's Side-Bet Theory. Social Forces, 47, 475-479.

Rotondi, Jr. T. (1975). Organisation identification and group involvement. Academy of Management Journal, 18, 892-6.

Scholl, R. (1981). Differentiating organisational commitment from expectancy as a motivating force. Academy of Management Review, 4, 589-599.

Scott, W. R. (1965). Reactions to supervision in a heterogenous professional organisation. Administrative Science Quarterly, 10, 65-81.

Scott, W. R. (1966). Professionals in bureaucraciesareas of conflict. In H. M. Vollmer \& D. L. Mills (Eds.), Professionalisation, Englewood Cliffs, NJ: Prentice-Hall, 265-267.

Sorensen, J. E., \& Sorensen, T. L.(1974). The conflict of professionals in bureaucratic organisations. Administrative Science Quarterly, 19, 98-106.

Staw, B. M., \& Salancik, G. R. (Eds.). (1977). New Directions in Organisational Behaviour. Chicago: St. Claire Press. 
Steers, R. M., \& Porter, L. W. (1983). Employee commitment to organisations. In R. Steers \& L. Porter (eds.), Motivation and Work Behaviour. McGraw Hill.

Stefy, B. D., \& Jones, J. W. (1988). The impact of family and career planning variables on the organisational, career and community commitment of professional women. Journal of Vocational Behaviour, 32, 196-212.

Vandenverghe, C. (1996). Assessing organisational commitment in a belgian context: Evidence for the three dimensional model. Applied Psychology: An International Review, 45 (4), 371-386.

Yallace, J. E. (1995). Organisational and (1) professional commitment in professional and non-professional organisations. Administrative Science Quarterly, 40, 228-255.
Wallace, J. E. (1993). Professional and organisational commitment: Compatible or incompatible? Journal of Vocational Behaviour, 42, 333-349.

Wiener, Y. (1982). Commitment in organisations: A normative view. Academy of Management Review, 7, 418-425.

Wiener,Y., \& Vardi, Y. (1980). Relationships between job, organisation and career commitments and work outcomes- an integrative approach. Organisational Behaviour and Human Performance, 26, 81-96.

Zain, A. Y. (1996). Quality of worklife and organisational commitment: A study of non-supervisory employees in Malaysian organisations. PhD Thesis. University of Strathclyde.

\section{Appendix}

\section{Table 1}

Definitions of organisational commitment

The attachment of an individual's fund of affectivity and emotion to the group (Kanter, 1968)

An attitude or an orientation toward the organisation which links or attaches the identity of the person to the rganisation (Sheldon, 1971)

The process by which the goals of the organisation and those of the individual become increasingly integrated or congruent (Hall, Schneider, \& Nygren, 1970)

- A partisan, affective attachment to the goals and values of the organisation to one's role in relation to goals and Walues, and to the organisation for its own sake, apart from its purely instrumental worth (Buchanan, 1974)

The relative strength of an individual's identification with and involvement in a particular organisation (Mowday, Porter, \& Steers, 1982)

Profit associated with continued participation and a cost associated with leaving (Kanter, 1968)

A structural phenomenon which occurs as a result of individual-organisational transactions and alterations in sidebets or investments over time (Hrebiniak \& Alutto, 1972)

The totality of internalised normative pressures to act in a way which meets organisational goals and interests (Wiener, 1982)

The committed employee considers it morally right to stay in the company, regardless of how much status enhancement or satisfaction the firm gives him or her over the years (Marsh \& Mannari, 1977) 
Table 2

Rotated Component Matrix

$\begin{array}{llll}\text { Item Measures of } & \text { Factor 1 } & \text { Factor 2 } & \text { Factor 3 } \\ \text { the Dimensions of } & & & \\ \text { Organisational Commitment } & & & \end{array}$

$\begin{array}{ll}\text { KON6 } & .772 \\ \text { KOA3 } & .742 \\ \text { KOA6 } & .730 \\ \text { KOA5 } & .725 \\ \text { KON4 } & .721 \\ \text { KOA4 } & .710 \\ \text { KON5 } & .665 \\ \text { KOA1 } & .639 \\ \text { KON3 } & .617 \\ \text { KON2 } & .592 \\ \text { KOA2 } & .584\end{array}$

a. KOA Affective commitment

. KOB Continuance commitment

c. KON Normative commitment

Extraction Method: Principal Component Analysis

Rotation Method: Varimax with Kaiser Normalisation 